\title{
Adolescent girls
}

Population Council

Follow this and additional works at: https://knowledgecommons.popcouncil.org/ series_newsletters_momentum How does access to this work benefit you? Let us know!

\section{Recommended Citation}

"Adolescent girls," Momentum newsletter. New York: Population Council, 2013. 

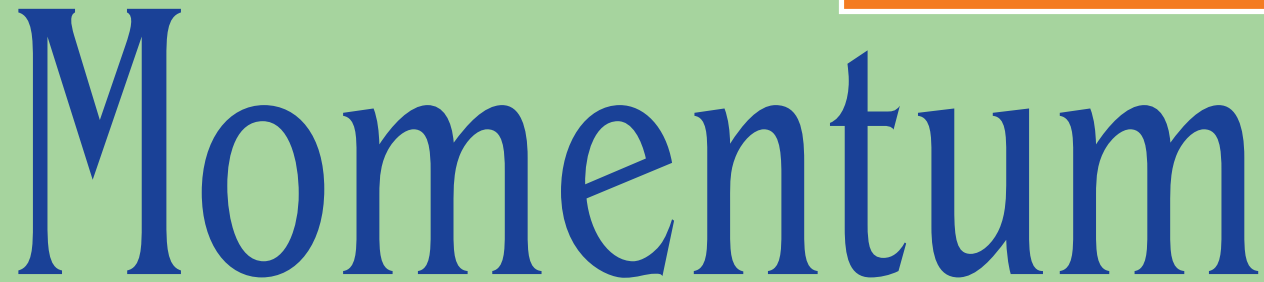

NOVEMBER 2013

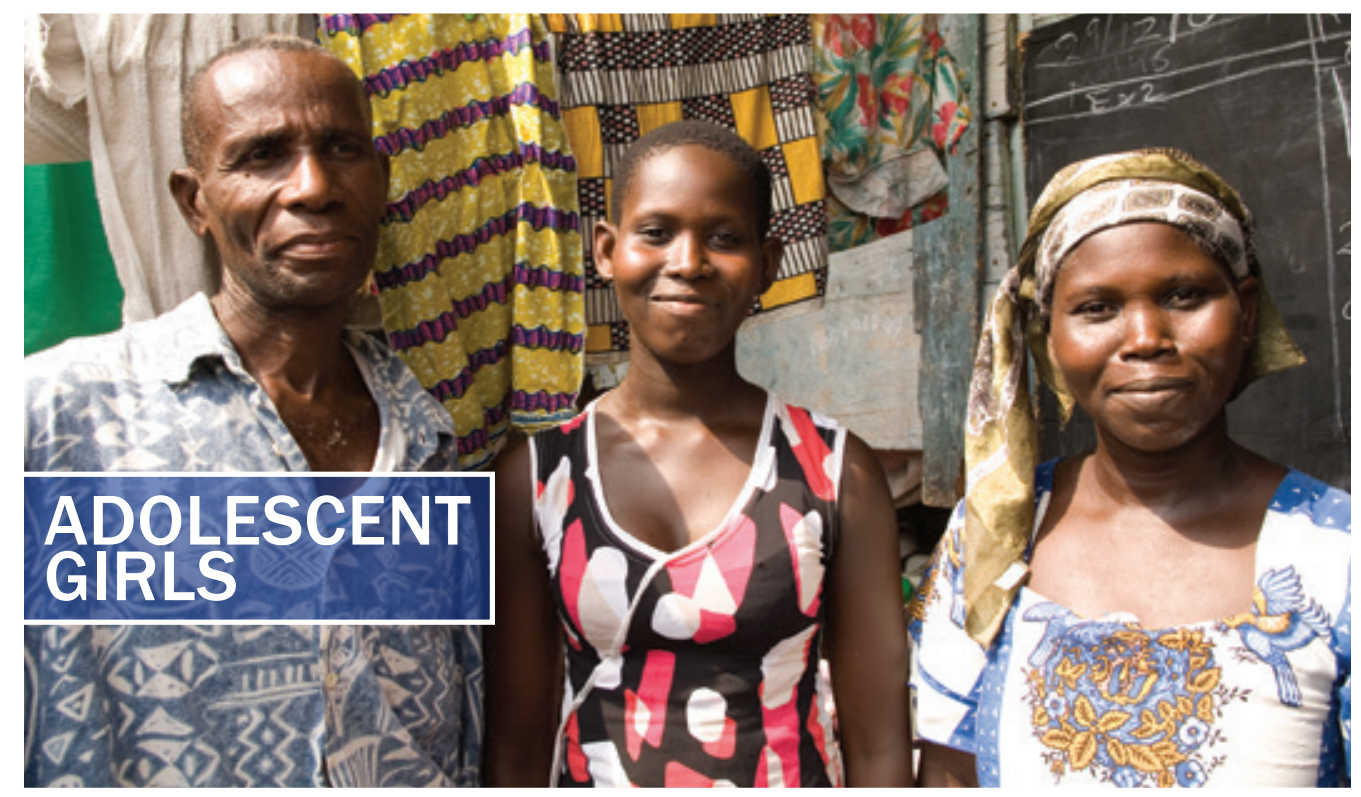

The Population Council designs and evaluates programs that give girls the skills to improve their social, economic, and educational outcomes and put them on a path to healthy, productive adulthood.

IN THIS ISSUE:

PRESIDENT'S MESSAGE: GIRLS LEADING THE WAY

DELAYING CHILD MARRIAGE IN SUB-SAHARAN AFRICA

GIRLS ON THE MOVE

PROTECTING GIRLS FROM GENDER-BASED VIOLENCE

THE EFFECT OF TEENAGE PREGNANCY ON GIRLS' SCHOOLING

ISHRAQ: A SAFE SPACE FOR GIRLS TO LEARN, PLAY, AND GROW

PROFILES: ALEJANDRA COLOM, PROGRAM COORDINATOR IN GUATEMALA, AND ANDREA EDLOW, COUNCIL DONOR

\begin{tabular}{l|l}
$Y$ & IDEA S \\
A & EVIDENCE \\
R & IMPACT \\
S & IMPA
\end{tabular}




\section{GIRLS IN DEVELOPING COUNTRIES FACE SERIOUS OBSTACLES}

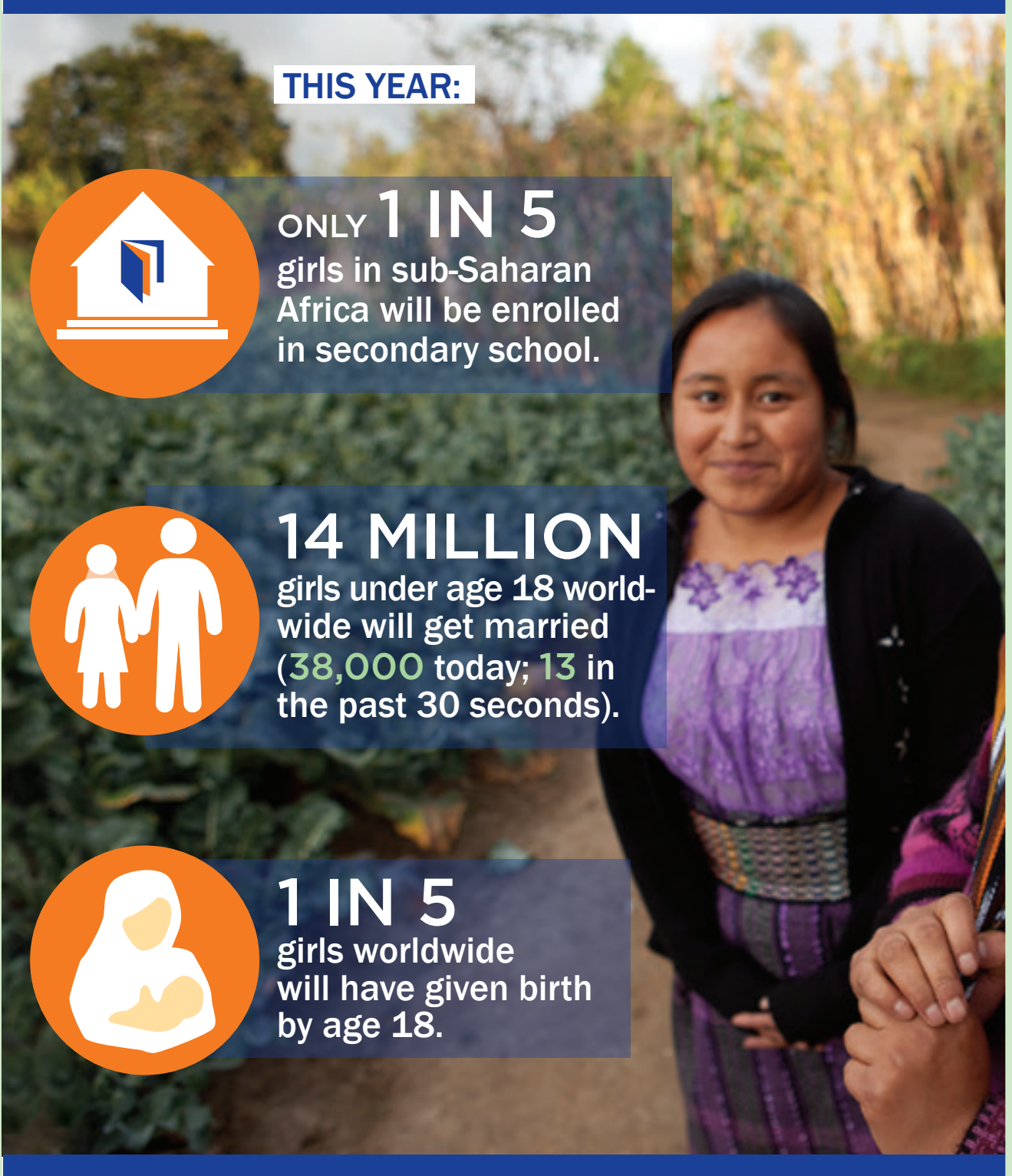

THE POSITIVE EFFECTS OF INVESTING IN GIRLS ARE UNDENIABLE

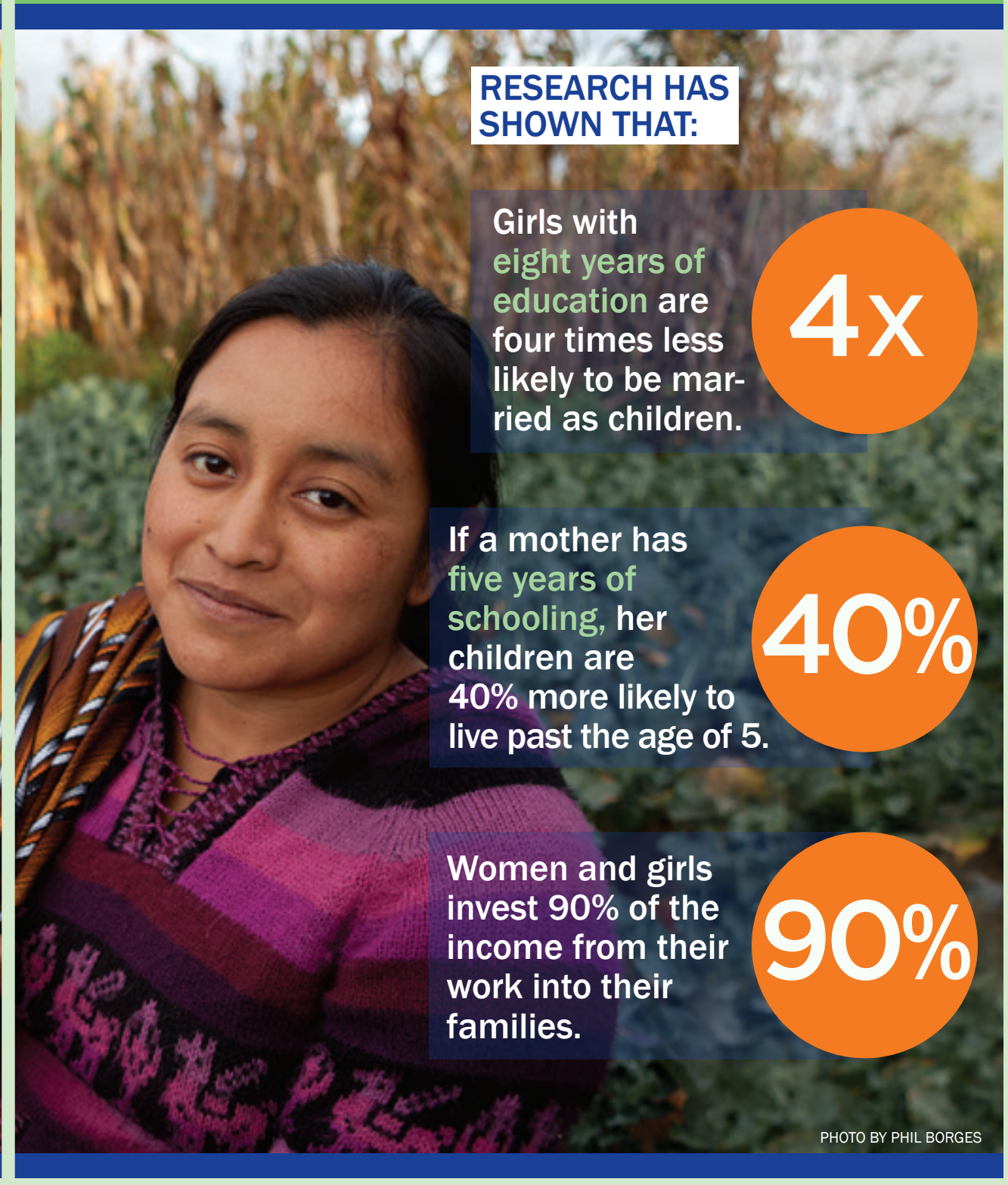




\section{GIRLS LEADING THE WAY}

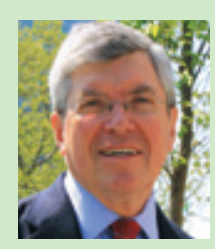

by Peter J. Donaldson

By the time Tigest turned 12, her family in the rural Amhara region of Ethiopia found it too costly to keep her in school and felt she was ready for marriage. In 2012, Tigest joined Berhane Hewan (Light for Eve), a Population Council initiative to provide unmarried adolescent girls with support to stay in school and provide communities with information on the negative consequences of child marriage. Since then, Tigest has remained in school and her parents have agreed to postpone her marriage.

This year, Berhane Hewan received first prize in a UNFPA contest to identify good practices related to adolescents and youth. The project, conducted in collaboration with the Ethiopia Ministry of Women, Children and Youth Affairs, has reached more than 20,000 girls. Council researchers are examining which aspects of the program are the most cost-effective ways to reduce child marriage.

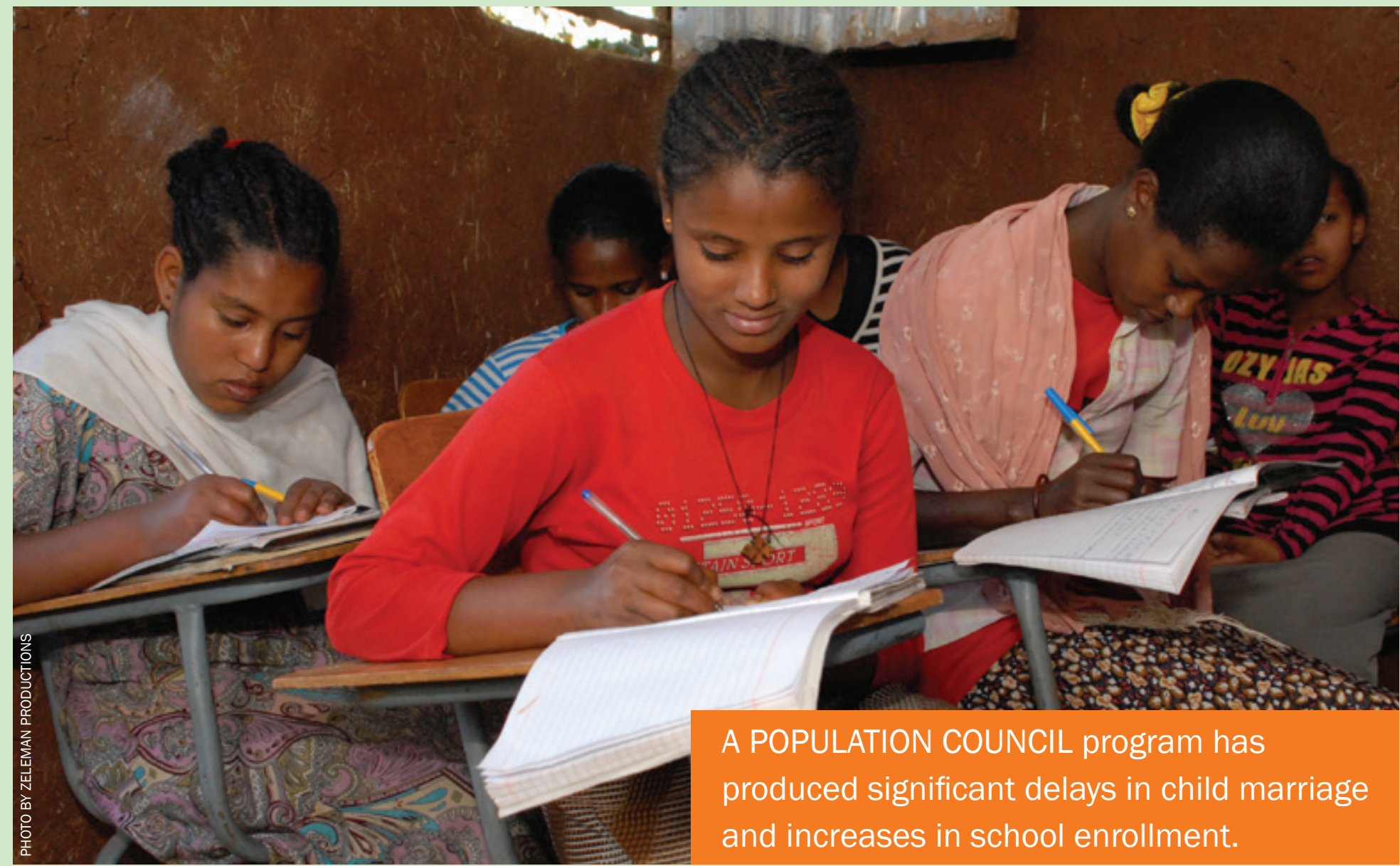

The Council is building a large body of research evaluating programs to improve the lives of adolescent girls. In Bangladesh, Burkina Faso, Ethiopia, Guatemala, India, Tanzania, and Zambia, more than 42,000 adolescent girls are participating in randomized, controlled trials-the gold standard of research-to evaluate different interventions. We are beginning a five-year project to study ways to improve the wellbeing of 100,000 poor and vulnerable girls in six states of northern Nigeria. Study findings will help governments and NGOs invest their resources in areas that will make the biggest difference in the lives of these girls.
In this issue of Momentum, you will read about how the Council is collecting evidence about how to help girls delay marriage (page 4 ), new data that challenges conventional wisdom about migrant girls (page 6), effective ways to address violence against girls (page 8), evidence about the impact of pregnancy on girls' schooling (page 10), and how another Council-supported program improves educational opportunities for the poorest girls in Upper Egypt (page 12). On pages 14-15, Alejandra Colom, who oversees the Council's programs in Guatemala, describes her work, and Dr. Andrea Edlow, a donor to the Council, talks about her support.
The Population Council designs and evaluates programs that give girls the skills to improve their social, economic, and educational outcomes, safeguard their reproductive health, and put them on a path to healthy, productive adulthood. When a girl learns to read, write, do numbers, and safeguard her health, there is a multiplier effect that improves her family's and her community's chances for the future. 


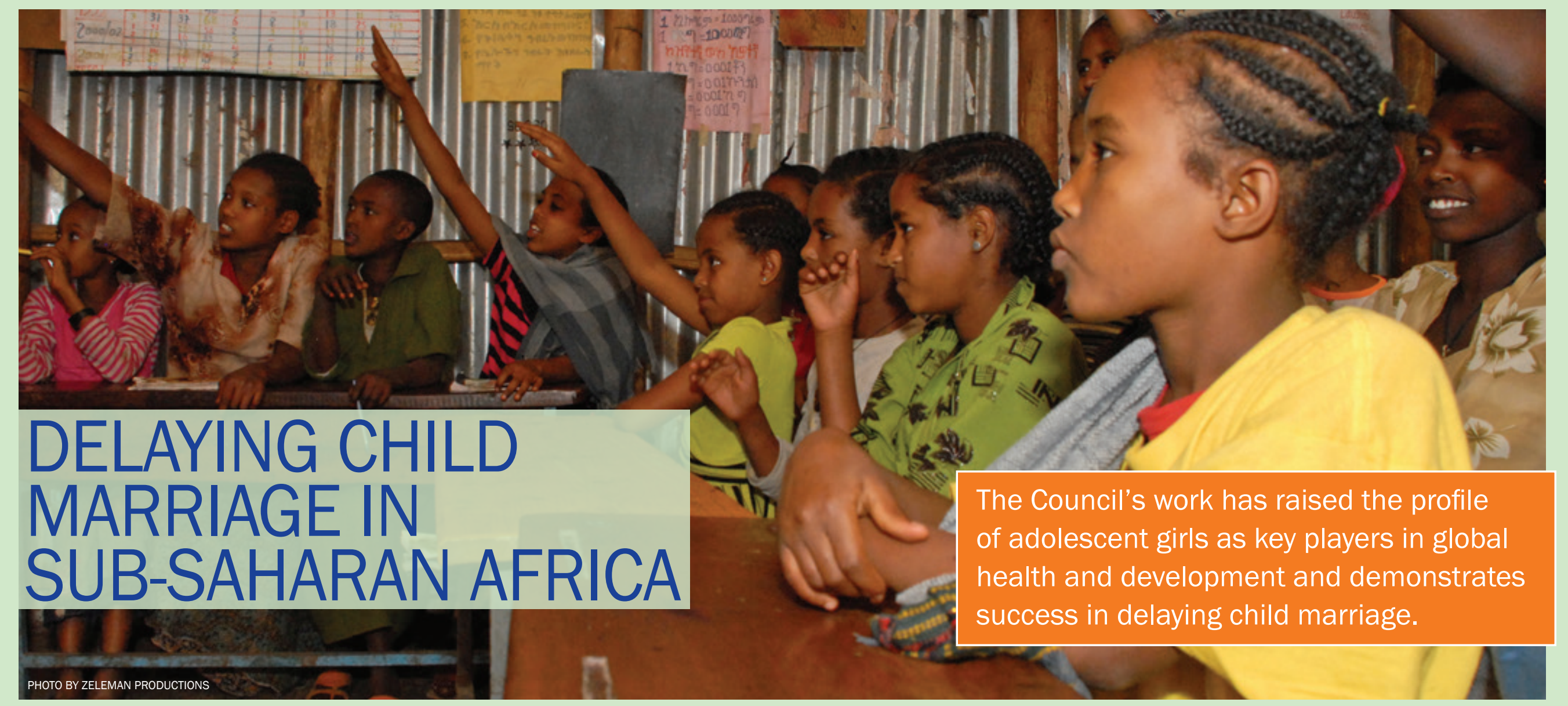

THE PROBLEM child marriage abruptly ends a girl's childhood and disrupts her education, forcing her to take on roles for which she is not emotionally and physically ready. The practice-which occurs before a girl reaches age 18 and sometimes as young as age 5-not only violates a girl's human rights and endangers her health, but also often anchors her in poverty. In many cases married girls are forced into sex, and they are likely to become mothers before their bodies and minds are mature. Many girls who marry early have a husband who is considerably older, and have limited or no household authority. If current trends continue, between 2011 and 2020 more than 140 million girls worldwide will become child brides.
THE PROGRESS Population Council research in Ethiopia demonstrated that it is possible to increase the age of marriage in locations where child marriage is entrenched. Through a partnership with local government in the rural Amhara region, where rates of child marriage are among the highest in the world, unmarried adolescent girls were provided with school supplies to encourage families to keep them in school and unmarried. Community-based mentors and village priests also worked to raise communities' awareness of the dangers of child marriage. Families were also promised a conditional cash transfer (in the form of livestock) if a girl remained unmarried and in school. An evaluation of this approach found that girls aged 10-14 were 90 percent less likely to be married in the area where the program was implemented than girls in the area that did not have the program, and three times more likely to be in school. Council researchers are now implementing multiple approaches in different districts and collecting data on associated costs. The results of the research will give the Ethiopian government information regarding how to expand successful approaches across the country. The Council is also collaborating with governments and local NGOs to introduce these approaches in Burkina Faso and Tanzania.
THE IMPACT In Ethiopia, the Population Council conducted one of the first rigorously evaluated projects with the explicit objective of increasing the age at marriage. The Council is one of the few organizations whose programs, in collaboration with local partners in sub-Saharan Africa, have demonstrated significant delays in marriage and increases in school enrollment.

DONORS AND PARTNERS Amhara Regional Bureau of Women, Children, and Youth; Ethiopia Ministry of Women, Children, and Youth Affairs; Tabora Development Foundation Trust; US Agency for International Development 


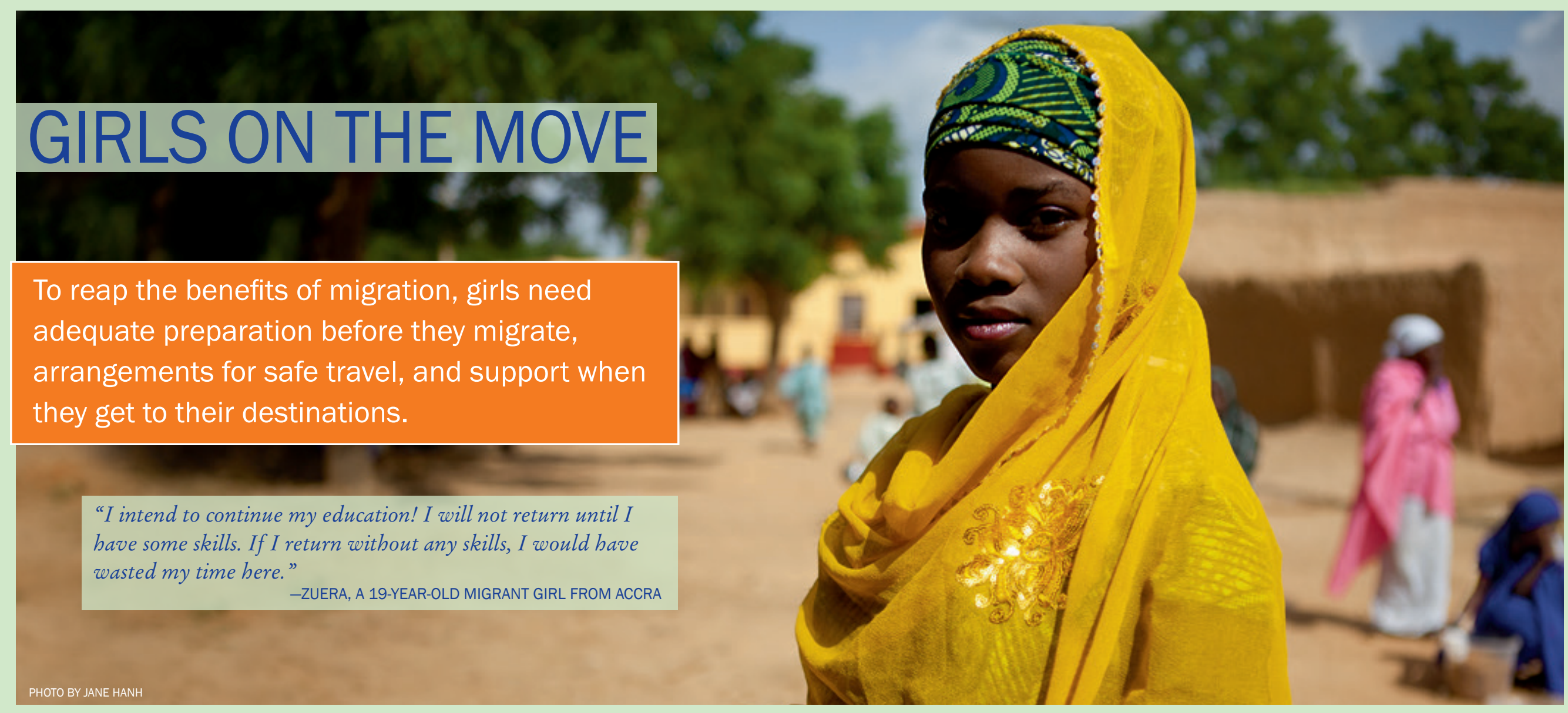

THE PROBLEM By the year 2030, more than half of the population in most developing countries will live in cities. Much of the growth is attributed to city-bound migrants, many of whom are adolescent girls. Little research has examined the social and economic drivers of internal migration for adolescent girls in developing countries, and the links between migration, risk, and opportunity. Current programs and policies aimed at helping migrants largely ignore adolescent girls, and the few policies and programs that attempt to reach vulnerable migrant girls often miss the mark. They benefit more advantaged girls or male migrants rather than the most vulnerable girls, or they view migration negatively, as if it were a problem that should be fixed-without acknowledging its potential benefits.

THE PROGRESS After reviewing the literature, analyzing large datasets, and commissioning more than 15 studies, Population Council researchers published Girls on the Move: Adolescent Girls \& Migration in the Developing World. The researchers found that migration does carry risk, but for many girls it can lead to greater autonomy, opportunity, and economic stability. To reap the benefits of migration, girls need adequate preparation before they migrate, arrangements for safe travel, and support when they get to their destinations. Without such resources and support, migration can be risky.
Girls on the Move makes key recommendations for improving the lives of girls who migrate. These include: filling critical evidence gaps to shed light on migrant girls' experiences and to evaluate and improve programs; connecting girls to safe places to stay, services, and networks upon arrival; creating time and space for migrant girls to meet with peers, mentors, and support networks; and maximizing the benefits and minimizing the risks of migration for adolescent girls by increasing their visibility in policy engagement and advocacy efforts.

THE IMPACT “The report is important in casting a new light and bringing unexpected findings about the role of mobility in opening up opportunities," says Jeni Klugman, director of Gender and Development at the World Bank. To date, Girls on the Move has been downloaded more than 5,000 times, highlighted in popular media, and widely disseminated to stakeholders. "It's important scholarship, and it's important for the way that it translates a lot of seemingly academic information into real-life contexts," said Blair A. Ruble, director of the Global Sustainability and Resilience Program at the Wilson Center, a research initiative in Washington, DC.

The full report can be downloaded at www.popcouncil.org/GirlsOnTheMove

DONORS AND PARTNERS The Nike Foundation, United Nations Foundation 


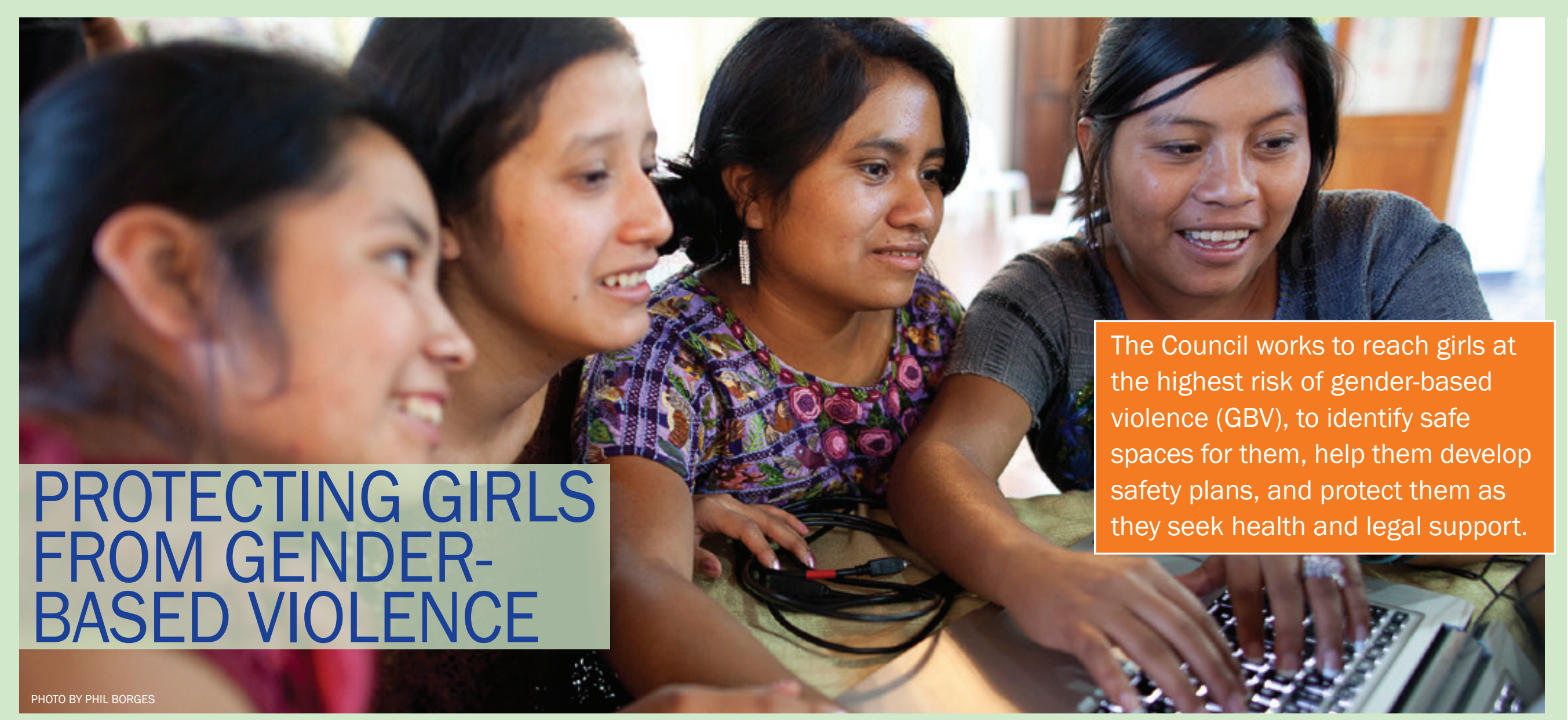

THE PROBLEM According to UN Women, about 150 million girls under age 18 are victims of sexual violence every year. Effects can be emotionally and physically devastating. Long-term health effects can include sexually transmitted infections, HIV/ AIDS, and unwanted pregnancy. Violence can also limit a girl's opportunity for education if a school is unsafe, hindering a girl's prospect of earning a sustainable income.

THE PROGRESS The Council works to identify the causes and consequences of gender inequality and GBV, and conducts and evaluates programs that build the protective assets of adolescent girls.
In two countries, the Council is working to strengthen girls' skills, knowledge, and safety nets in an effort to reduce their experience of violence. In Guatemala, the Council, with local and international partners, started Abriendo Oportunidades (Creating Opportunities) to provide vulnerable indigenous Mayan girls with skill-building, mentorship, and leadership opportunities. One example is an activity called "safescaping," in which girls use GPS technology to map safe and unsafe areas in their communities and present the maps to community leaders to prompt discussions about improving girls' safety.

Work is also being done in Bangladesh to create safe spaces and increase GBV awareness. Three years ago, the Council began the Growing Up Safe and Healthy (SAFE) project, which refers girls who report abuse within the home to joint health and legal services in a one-stop setting. SAFE also offers sessions for women and girls on how to protect themselves against sexual and reproductive health risks and GBV.

THE IMPACT Both of these projects engage directly with girls to strengthen their social networks, resources, and safety nets to reduce their vulnerability to violence. Communities in Guatemala have responded to girls' safescaping maps by establishing safety commissions to track girls' safety throughout the year and by institutionaliz- ing safescaping via the Ministry of Education. The Council's work in Bangladesh is the first of its kind to focus on consent and choice as critical parameters in asserting sexual and reproductive health rights among girls. Evaluation results are anticipated in 2014.

DONORS AND PARTNERS Bangladesh Legal Aid and Services Trust; Bill \& Melinda Gates Foundation; Embassy of the Kingdom of the Netherlands; The William and Flora Hewlett Foundation; International Centre for Diarrhoeal Disease Research, Bangladesh (icddr,b); Marie Stopes/Bangladesh; The Andrew W. Mellon Foundation; UK Department for International Development; We Can End All Violence Against Women/Bangladesh 


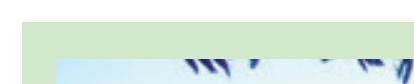

THE EFFECT'
OF TEENAGE
PREGNANCY
ON GIRLS
SCHOOLING

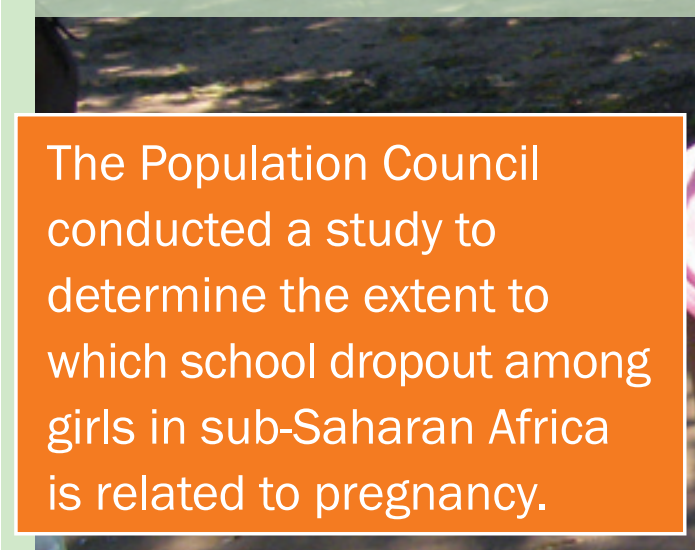

-

THE PROBLEM More than 14 percent of girls aged 15-19 in sub-Saharan Africa get pregnant, and in Malawi one in every four teen girls has had a child. Girls who get pregnant do not complete as many years of schooling as those who do not get pregnant. Would these girls who became pregnant have left school anyway for other reasons? Without a better understanding of this situation, it is difficult to create effective programming to prevent teen pregnancy and keep girls in school.

THE PROGRESS Since 2007, the Population Council has conducted the
Malawi Schooling and Adolescent Study, a multi-year survey following 2,649 adolescents who were aged 14-17 when they were first interviewed. The students enrolled in the study are from two districts of Malawi, a country with high primary school enrollment, but where more than one-third of girls aged 20-24 gave birth before the age of 18. Data from this study illuminate the various reasons girls drop out of school.

THE IMPACT The study found that among girls who were sexually active, those who became pregnant had been doing just as well in school as those who did not be- come pregnant. "That finding suggests that these students were as committed to school as their peers who were sexually active and did not get pregnant," said Barbara Mensch, the Council's senior study researcher.

The study also found that girls who left school because of childbearing were less likely to return than those who left for other reasons. Young mothers wanting to reenroll faced many barriers, including extensive paperwork and rules that prevented reenrollment until six months after giving birth. "If we can increase access to family planning for sexually active adolescents, we 


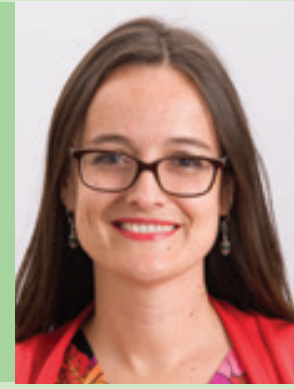

\section{ALEJANDRA COLOM}

PROGRAM COORDINATOR IN THE POPULATION COUNCIL'S GUATEMALA OFFICE

\section{ANDREA EDLOW}

COUNCIL DONOR AND OB/GYN AT TUFTS MEDICAL CENTER IN BOSTON

What is a success that you are proud of?

Some funding is wasted on programs that are not responsive to local needs. I would say that our program, Abriendo Oportunidadesa national program providing the most vulnerable indigenous Mayan girls and young women with professional mentorship and leadership opportunities-is one of the most responsive in Guatemala to input from adolescent girls. Proof of this is the high leve of acceptance among mothers and the girls who participate.

What do you wish people knew about the Population Council?

The Council is different from other organizations because its interventions are evidencebased. Programs are designed through proven methodologies, and research activities are conducted under strict standards. Our rightsbased approach to working with vulnerable girls and adolescents is different from others because it addresses issues that compromise the health and well-being of participants in a culturally relevant way.
I was interested in women's health and empowerment at an early age. In high school in New Mexico, I worked with Planned Parenthood to study sex education. I saw that women's ability to stay in school, and ultimately to achieve their personal goals and full potential, depended on accurate knowledge of how to prevent pregnancy and on the availability of effective contraception. In medical school, obstetrics and gynecology was a natural fit for my long-standing commitment to women's health.

WHY I GIVE TO THE POPULATION COUNCIL

remind myself of what Martin Luther King said: "The arc of the moral universe is long, but it bends toward justice." My generation is now tasked with actively bending the moral arc toward justice, so as not to reverse the progress achieved by our mothers' generation. It is our obligation to take up this cause.

The Population Council's mission aligns with my personal beliefs and work as an OB/GYN. The ability to decide if and when to have children has a direct impact, not only on the lives of women planning their families, but on the economic and mora strength of the societies in which these women live.

I know from my experience working with women that the choice of contraceptive is a personal one and there is no "one size fits all." What may work for a 45-yearold woman in Boston, may not work for 20-year-old in Zambia. The availability of a wide variety of contraceptives is crucial to ensuring that women can find the method that works best for them.

The pendulum seems to be swinging away from a woman's right to selfdetermination, both in the US and abroad. Whenever I feel down about attempts to restrict women's access to family planning and safe abortion, I
My mother-in-law, Mary Edlow, has dedicated her career to helping vulnerable women improve their circumstances, so the Population and priorities of my in-laws, Ken and Mary. I am grateful for their generous support of the Population Council.

The Council blends research and development with local and global outreach. It recognizes that women's and HIV prevention products is critical to the success of all members of society, including men, women, and children. Supporting the Population Council is for everyone and benefits everyone. Council's mission fulfilled the interests access to family planning resources are more visible now, but relev settings is needed to reach the most vulnerable populations. 
More than 3,000 girls have participated in the Ishraq program for 12-15-year-old out-of-school girls in rural Upper Egypt-the least developed and most economically disadvantaged region of the country-with mentors and safe spaces for informal learning and sports. The program, launched in 2001, is one of the Council's original girls' empowerment initiatives.

"Because I love to learn and wanted to know how to read and write, I decided to join Ishraq. The promoters were about the same age as we are, so we were not afraid of them and they treated us well. We needed someone we can trust to talk to about personal issues that we can't discuss with our mothers. I was surprised to learn that circumcision is harmful to girls. I watched sports only on television, but I really wanted to practice sports for real. It is only through Ishraq that this dream came true."

-DINA, ISHRAQ PROGRAM PARTICIPANT

INVESTING IN THE POOREST GIRLS IN THE POOREST COMMUNITIES HELPS FAMILIES, COMMUNITIES, AND NATIONS BUILD HEALTHIER AND MORE PRODUCTIVE FUTURES.

The Population Council's research in more than a dozen countries demonstrates that when girls like Dina are given mentoring, social support, health information, financial literacy, and educational opportunities, they can begin to overcome poverty and thrive. Excluding adolescent girls from school, community participation, and meaningful livelihoods has a substantial negative impact on economic growth. By supporting the Council today, you help us and our partners conduct research to promote program and policy change to help girls lead more productive and healthier lives.

Sign up for the Population Council e-mail list: www.popcouncil.org/signup

Support the Population Council:

www.popcouncil.org/supporting

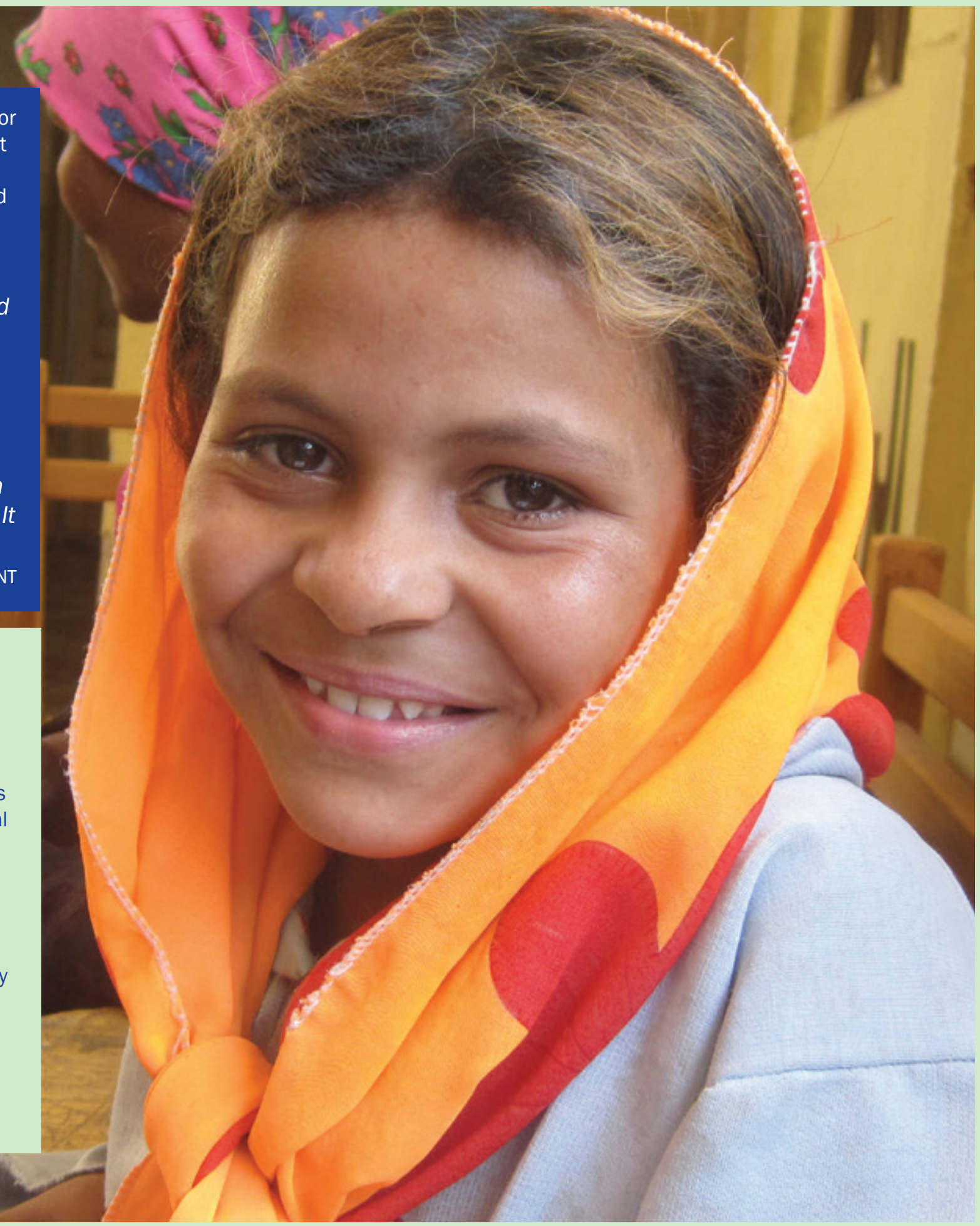


등융요

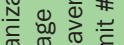

त्ञ⿰⿺乚一匕

히웡

艺 ம்

흠

ì 